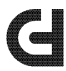 \\ COUNTERFUTURES \\ Left thought \& practice Aotearoa
}

\section{THREE}




\title{
Editorial: On travelling future trails
}

\author{
Warwick Tie
}

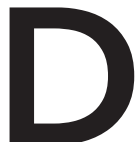

ESPITE LOCAL TALK of a rock-star economy and the like, the continuing legacy of neoliberal administration provides few reasons to celebrate. The situation reminds me of the adverts in which ordinary people are seen celebrating the news that big banks have increased their profits. It does not really happen. Those achievements that do appear in the media for shared salute all too frequently show themselves to be little more than agglomerations of individual actions. Think of the much vaunted Gross Domestic Product (GDP) and of significance attributed to growth in those terms. The abstract character of the thing that GDP appears to calculate-products achieving market value-has no meaning outside the actions of flesh and blood people who populate the space within which money's movement is being measured. The greater the mass of productive individuals, all other things being equal (so the economists like to say), the 
stronger the financial indicator. Moreover, neoliberal markers of shared success all too easily lack a moral compass. Think of GDP again: its mechanisms are just as liable to include economic productivity propelled by human trafficking as environmental concern. It cannot differentiate.

Limp markers of shared success are not the only legacy of the neoliberal project. Systemic policy failures also now feature. Their appearance has taken some time to materialise, as with the symptoms which came to plague that other great neoclassical school of economic reform, Keynesianism (principally, of simultaneous inflation and rising unemployment during the 1970s in the major economies-'stagflation'). The onset of what Marxian economist Michael Roberts is calling the 'long depression'_-associated with 2008's Global Financial Crisis-coupled with speculative housing-market bubbles and the intensification of ecologically-encroaching industries, now embed crises across various fields. Realised now locally as mass homelessness, poverty, extensive levels of freshwater pollution, widespread poisoning and the like, these crises condense anew the unresolved issues associated with histories of colonisation, patriarchal domination, and economic exploitation. In the face of such, ideological mechanisms can be seen routinely going into states of overdrive, reminiscent of the theatre of the absurd: there is no housing crisis, just a deepening demand for emergency housing. ${ }^{2}$

Amidst this mix of shallow markers of collective achievement and systemic policy failure, one field of social activity does present itself as being in a state of genuine growth-punishment, and punishment through incarceration more particularly.

1 See Naoise McDongah, this issue.

2 Sam Sachdeva, 'John Key says no Auckland housing crisis, but 76 per cent of voter want more action', Stuff, accessed 3 April 2017, http://www.stuff.co.nz/business/industries/80320513/John-Key-says-no-Auckland-housing-crisis-but-76-percent-of-voters-want-more-action. 
The stellar climb of local incarceration rates was presented as an indicator of policy success by the recently outgoing Minister of Corrections. ${ }^{3}$ In a period witnessing the socially destructive power of globally-financialised capital, indications of social orderliness, no matter how imposed, seemingly now become markers of collective achievement. The initiative for punitive penal policies had, for a period of time during the 1990s-2000s, been driven by populist politics (of 'penal populism'). ${ }^{4}$ Advocates of 'sensible sentencing' became, for a time, the face of a new kind of expertise. The shift of initiative back towards the state indicates in part a broader movement within neoliberalism towards authoritarian forms of governance. ${ }^{5}$ Of less significance now is the obsession that had characterised the neoliberal project, that of the wellchoosing individual. In the absence of an equitable distribution of economic capacities to choose (of what to buy), receptiveness to the rhetoric was bound to plateau. Moreover, there were always going to be groups whose exclusion from participation in the project made them a problem at the outset for the reform's architects. The challenge for the state has since become one of popularising its use of invasive forms of social ordering, such that increased levels of imprisonment might seem and feel reasonable to the electorates.

The relative success of that move has been demonstrated, in part, by the inability of centrist opposition parties to produce full-frontal critiques of this shift. The centrality of punishment to neoliberal governance has not been systematically questioned. Instead, criticisms have tended to get framed in ways that are oblique to the authoritarian retooling of neoliberal governance,

3 Judith Collings 'Explaining the high prison record', The New Zealand Herald, 21 March 2016.

4 John Pratt, Penal Populism: Key Ideas in Criminology. Abingdon 2007.

$5 \quad$ William Davies, 'The New Neoliberalism', New Left Review September-October, 101 2016, 121-34. 
such as through denunciation of privatised prison management. ${ }^{6}$

To suggest that the use of incarceration occurs at a time of systemic policy failure, when the rhetoric of 'choice' is being displaced by a harshly differentiating rule of law, does little more perhaps than refresh Angela Davis' much-quoted observation that prison operates to save good-minded people from thinking about the failures of government. ${ }^{7}$

Work remains to be done here, however, given the role that incarceration has come to play as a contender for collective success. In part, the work to be done is framed by the concrete realities of Aotearoa/New Zealand at this time. As simple as that proposition sounds, considerable room exists for disagreement over the forms these material conditions take, and of their relative significance in the shaping of current situations, and for the seeding of new futures. In broad terms there exists colonisation, patriarchal domination, and the economic exploitation intrinsic to capitalist relations. There also exist the forms of domination associated with heteronormativity and ableism. In terms of the objects that then give immediate shape to punishment and incarceration, a wide range of items exist and differing sets of these objects can be found in the pieces which follow. These include prisons and prison wardens, residential youth facilities and social workers, psychiatric hospitals and ECT machines, courtroom culture and sentencing procedures, law and policing. They also include gangs, labour-exploitation, personal stories, and fetid streams. They also spread out to include Shakespeare and experimental controls, crimes and strip-searches. As to which objects should make up the list is, in part, the challenge facing the

6 See, for example, "Private prisons aren't working'-Labour slams Serco after contract dumped', One News, TVNZ, accessed 3 April 2017, https:/www.tvnz.co.nz/ one-news/new-zealand/private-prisons-arent-working-labour-slams-serco-aftercontract-dumped

$7 \quad$ Angela Davis, Are Prisons Obsolete? New York 2003, p. 16. 
Left as it seeks to mobilise tractive forces around incarceration. Much is at stake in that question, as pathways of change are set in train by the objects said to matter.

In addition to the concrete objects out of which incarceration is now made, the phenomenon is also in part an idea. To reframe the point in more analytical terms, the normalisation of imprisonment as punishment depends upon the sustaining force of ideology. Commonly, the supporting ideology for incarceration is understood to be 'law and order', the idea that law stands on the boundary between order and chaos. It is a boundary to be firmly policed, so the ideology goes: 'the Thin Blue Line' is to be defended at all costs because any lapse in policing risks descent into chaos.

Alternatives to that ideology include 'reform' and 'abolition'. Both can be found in the pages which follow. Reform perceives a legitimate role for the institutions of justice-of law, police, prisons - while recognising a need for politically marginalised perspectives to shape the formation of those institutions' purposes and practices. They might be repurposed, as Tracey McIntosh and Stan Coster argue here, through the use of insights produced through 'Indigenous insider knowledge', of intimate knowledge of how state care/punishment operates. Abolition presents reform as being intrinsic to the logic of law and order and, as a consequence, a means by which the latter is sustained. According to the logic of abolition, only a wholesale departure from punishment can inaugurate social relationships within which humans have a chance of coexisting across their differences.

Incarceration is more, however, than this fusion of material objects and ideology. The legacy coming from the critical Marxian tradition known as the Frankfurt School suggests that it will also be, in part, composed of affective investments by 
which each and every person is knitted together. ${ }^{8}$ These affective investments are themselves maintained through the particular kinds of social bond through which people engage with each other. ${ }^{9}$ So too with prospects that are put forward for the reform or abolition of the prison. It is attention to this issue that can set the Left project apart from those programmes associated with the relatively unsophisticated pursuit of law and order, or from simple social-democratic reform. It recognises how each person is formed as a social being within familial and cultural regimes of punishment and reward. We come to recognise ourselves and others, in part, as a consequence of how these systems have operated. Prior private experiences of punishment influence how individuals engage in the present with public punishment. Psychoanalysts call this transference. Each remains marked.

Perceptions as to how such bonds can function vary in the contributions that follow. A recurring perspective is that alternatives to incarceration might be imagined in ways that displace the power such investments might otherwise have, changing how we relate to ourselves and others. The legacies of rewards and punishments through which we have each formed as social beings will always remain, but their effect can be lessened as a consequence of the empowering kinds of social connection offered by the new vision. Emblematic here is No Pride in Prisons' politically charged-yet highly reasonable, and scientifically justifiable-call for prison abolition. ${ }^{10}$ Alternatively, a social bond can be found at work in the description of Auckland's first prison that anticipates ongoing affective attachments to punishment,

8 See, for example, Herbert Marcuse, One Dimensional Man: Studies in the Ideologies of Advanced Industrial Society, Boston 1964.

9 For an introduction to the notion of social bonds of this kind, see Justin Clemens \& Russell Grigg, eds., Jacques Lacan and the Other Side of Psychoanalysis: Reflections on Seminar XVII, Durham 2006

10 See No Pride in Prisons, this issue. 
even as the topic of punishment is critically appraised. ${ }^{11}$ It is a bond that emerges not simply from the patterns of punishment through which each of us has been, in part, formed. Rather, it emerges from deep within the modernist culture of the colonising powers; from an impasse that, on the one hand, is routinely papered over by commonplace responses like laughter or feelings of satisfaction yet, on the other hand, warrants neither mirth nor pleasure. The bond (to be broken) is a wry indifference toward-if not complicity in-the (apparent) impossibility of resolution to that impasse.

At first glance, the complex map of punishment and incarceration provided by the various contributions-across these dimensions of ideology, material conditions, and affective investment-provides no readily recognisable way forward. It offers neither a single storyline to be followed nor a narrative of past events moving into future states. What it might mean to create strategies and to act differs, then, from what may be suggested by 'social planning' types of intervention. Rather, the pathway to be taken can only be made, as trite as it might sound, by walking it. The analytic with which we begin will always be an initial guide-that incarceration simultaneously comprises a complex set of concrete objects, ideologies, and affective investments. Beyond that starting point, however, a shared sense of purpose can be built only through the enacting of interventions that are collectively reflected upon, across socio-cultural differences. It is only the shared nature of that reflection which may make the pathway durable enough for ourselves, if not others, to take.

* $* \quad *$

11 See Mark Derby \& Warwick Tie, this issue. 
When a call for papers was sent out for this Issue, we envisaged that a range of papers would be submitted in addition to those on punishment and incarceration. It has proven the case, however, that the 'thematic' character of that call turned into something more akin to a 'Special Issue' on incarceration. Such was the interest. The Issue does contain, however, two pieces on matters other than punishment-brief 'interventions' by members of the editorial board on the occasion of Trump's inauguration as president of the United States. In the first of the interventions, Chamsy el-Ojeili locates Trump's election within a generalised move towards authoritarian populism that can be seen across various western democracies. In doing so, el-Ojeili asks about the extent to which this suggests Trump's election as being fascism born anew. He reviews that prospect in light of Michael Mann's definitive insights into the emergence of the inter-war fascisms of Europe and Japan.

In the second reflection on Trump's inauguration, Tim Corballis asks about the prospects for meaningful politics in a time that is characterised by a new kind of chasm. Lining that chasm are, on the one side, those who are satisfied that substantive political debate is no longer required (the 'post-political') and, on the other, those whose 'rage ... would wipe it [politics] away with a gesture' (the 'anti-political'). ${ }^{12}$ With so very little on offer from either option, it becomes tempting to choose the lesser of the two evils. What if, however, the lure of that lesser evil is the greatest evil of all?

We also have two book reviews, one on Nadim Bakshov's recent book through Zero Press on the university under capitalism, Against Capitalist Education: What is Education for? (reviewed by Peter Howland). The second review is of Michael Roberts' Marxist analysis of the global financial crisis (GCF), 
The Long Depression (reviewed by Naoise McDongah). Howland's review engages us fully in the Socratic style in which the book is written, humorously providing us with an experience of its strengths and limit-points. McDongah, likewise, presents The Long Depression in the manner in which its text is written-this time scholastic. His review clarifies for us, in a simple and straightforward manner, the issues at stake in the various debates around the causes of, and prospects emerging from, the GFC.

Opening the Issue as a whole is a kind of subject not frequently covered in Counterfutures: a history of Auckland's first prison. In addition to a gripping account of the 'feculent' gaol on Queen Street, as seen through the eyes of Wellington historian Mark Derby, the paper indicates how the idea of imprisonment here came to reflect the capitalism which accompanied the settlers. Emblematic of this is the assumption that the labour power of inmates should be expropriated, typically through their use on public works projects. The paper also points to the desires for reform amongst elements of the settlers, foretelling the incremental improvement of prison conditions through the twentieth century. As to how the critically-aware reader might then square up the satisfaction that inmates are no longer kept in states of abject poverty, with the observation that contemporary imprisonment perpetuates presuppositions particular to capitalism, is work this paper leaves unfinished.

The role that the capitalist abstraction of labour-power has played within the logic of imprisonment frames, also, the second article. Ian Anderson's 'Left backs working prisons' suggests that the expropriation of prison labour-which occurs under the contestable guise of rehabilitation-would be called, if under other conditions, slavery. The assumption that labour-power can be used in this way points, for Anderson, to a key mechanism through which inmates are made into a 'nonpublic'. A nonpublic is 'a disavowed population that doesn't necessarily emerge 
with an organised claim on recognition'. ${ }^{13}$ A politically important question then animates discussion, concerning how such a group might gain the kind of gravitational mass that may see demands issued on the part of its members. Anderson finds hope, in this regard, in the re-emergence of the abolitionist movement.

Anderson's notion of the 'inmate nonpublic' finds a fellow traveller in the article by Tracey McIntosh and Stan Coster. Here, the notion of the nonpublic become 'Indigenous insider knowledge'-that prospects for change in the prison system lie with a knowledge-base that comes only from intimate experience of being formed within/by that system. In the case of Coster, that system has included not only prison but also incarceration within residential youth facilities (coupled with awareness of other's experiences of psychiatric hospitalisation). Insider knowledge does not necessarily lead to a push for the abolition of prisons. As the authors note, 'Like those who have never been to prison, he [Stan] also cannot imagine a world without prison'. ${ }^{14}$ Rather, the knowledge that comes from intimate experiences of institutional practices suggests itself as a tool for the development of grass-roots initiatives, from which calls for wider systemic change might come.

Readers might note tensions across these articles between the ideas of reform and abolition. The gap between them is grappled with by John Buttle in 'Imagining an Aotearoa/New Zealand without prisons'. Building on the notion of 'transitional strategies', Buttle proposes that the abolition of prisons can only come about through a patient pursuit of 'decarceration'. The process of stemming the flow into prisons begins not with the institutions of imprisonment, but with those of policing and judicial sentencing. It is in these fields that the instigation of humble re-

13 Ian Anderson, this issue, p. 61. Original emphasis.

14 Tracey McIntosh \& Stan Coster, this issue, p. 92. 
forms might produce the conditions in which wholesale abolition might succeed. In conjunction with the dismantling of the prison architecture, forms of collective sanction/care that run askew to punishment will be required. The tradition of therapeutic communities is seen to offer much in that regard.

Prospects for the abolitionist project are considered further in an interview with Ti Lamusse, Emmy Rākete, and Sophie Morgan, who are members of the No Pride in Prisons collective. Born in an act of resistance to the inclusion of the Police and the Department of Corrections in the 2015 Gay Pride parade, No Pride in Prisons has come to view abolition as the only reasonable response to imprisonment. The interview canvasses why the collective pursues abolition rather than prison reform, how it organises with like-minded groups, how the group learns, and the challenges faced by abolitionism.

'In the car', by novelist Pip Adams, plays upon the ironies that punctuate the teaching of creative writing within prison walls. Set within a car journey to Rimutaka Prison for such a class, the piece dallies with possible reasons as to why such a maladaptive setting might work for learning of this kind. It reflects, in passing, upon the dynamic openness of narrated storylines when spoken not by those who speak for a living but, rather, by those who have learned to author. Even if (only) in prison. The gestural nature of the observation is befitting of the setting, is it not?- the piece may be read as asking-given the institutional status routinely given to therapeutic interventions that are paid to speak what is written.

'Demanding explanations', is an intervention that began as a book review and ended as a site of spirited debate. Greg Newbold's Crime, Law and Justice in New Zealand had been reviewed critically by fellow criminologist Ronald Kramer. Newbold was invited to reply. At stake between the review and the response is a set of questions about the social structures of 
crime and punishment in Aotearoa/New Zealand, and of questions about the impacts of each upon the other. What structures count? How does colonisation and neoliberalism affect both offending behaviour and institutional response, relative to the everyday actions of knowledgeable people? No resolution is reached on these matters. Instead, the impasse points to the contentious character of such debates. Answers which come to prevail shape the course of policing and penal policies, of imprisonment practices, and more besides. As such, much is at stake.

* $\quad * \quad *$

Counterfutures sets itself apart from the jokes sometimes heard about Readers' Digest. It is not a random collection of bits and pieces (from the Left, in this case). The collation of a set of texts has a meaning played out, in part, through the order in which they are made to appear. Yet, as observed earlier, there is no single story-line running through this set of articles, interventions, and interview; no party-line exists to be deciphered. Rather, the works collectively exhibit a considerable diversity on matters central to the understanding of punishment and incarceration: the objects that make up the phenomenon; the ideologies used to challenge the naturalness accorded to 'law and order'; and the affective investments held toward reward and punishment. Between this complex set of images and the overarching 'thing in itself' to which that set speaks_of 'punishment and incarceration'-there sits what we do. Moreover, it is only in how we actin the face of a public-punishment-now-presented-as-collectiveachievement-that possibilities for transformative change might form, and along whose trails we, along with others, might thereafter travel. 
If you like what you have read, please subscribe or donate.

\author{
G \\ COUNTERF UTURES \\ Left thought \& practice Aotearoa \\ (C) Copyright Counterfutures 2017
}

